\title{
Saving and Lifestyle of Young Indians
}

\author{
Anju Varghese ${ }^{1}$, Anit Ban $A^{2}$ \\ Amrita University, Amrita School of Arts And Sciences, Brahmasthamnam, Edappally North, Kochi , 682024, India
}

\begin{abstract}
Saving and lifestyle of individuals play an important role in economy. The Indian market is seeing a tremendous change in lifestyle of a common man. The saving habit of individual helps them to grow individually and whole as a society. Indians are among the most positive about their financial futures and have high savings and investment. The top investment goals for Indians are savings after retirement, buying a home etc. The consumption level has increased because of increase in level of income, change in attitudes towards consumption, availability of credits, changes in price of commodities. The study is done to know about the changes of lifestyle pattern among youth in relation to selected demographic elements and socio-economic characteristics factors. The lifestyle is explained with respect to consumption habits, fashion trends, entertainment, and use of technology. Consumer spending is categorized into regular spends and lifestyle spends. Regular spending includes the basic requirement life, while lifestyle spending includes spending on a computer, internet, car, cell phone, etc.
\end{abstract}

Keywords: Consumption behaviour, Savings, Lifestyle, Spending

\section{Introduction}

The spending habits differ for people in different sections of society. India's present population comprises of 1.31 billion people in which almost $50 \%$ of population is youth. The people in the middle class consider basic necessities, education of their children as their top priorities, followed by lifestyle goods. The rich class spends huge on luxury goods and on international brands. The super-rich class spends on ultra-luxury goods. It is observed that as income increases, people prefer to spend more on branded goods, shift to processed foods, and the expenditure on food, beverages, transport and communication also increases.

The shopping habits of Indians have changed due to their growing income, increase in the younger population, and the change in attitudes towards shopping. The desire to look and feel good is the factor for customers while making their purchase decisions. The growing disposable income is also making demand for consumer durables and eating in restaurants, going for movies, travelling is growing among Indians. Age is one of the major factors that affect the spending decisions of an individual. Youth in 20-24 years age group spend more on electronic items, home appliances and movies, entertainment, travelling. The spending habit of consumer is an important factor that affects the economic growth and development of any country. In the coming future, India and China are playing the key roles for in terms of growth in consumption, wages, and GDP in Asia.

\section{Objectives of the Study}

1) To study about socio- economic factors and influence on lifestyle and consumption pattern.

2) To know about the spending behaviour of youth.

3) To study about the spending habit of youth with the modern technology.

\section{Research Methodology}

The data collection is through Structured Questionnaire. The sampling method is simple random sampling.

- Primary Data
A questionnaire was prepared and the primary data was collected through survey method.

- Secondary Data

Websites, books were referred.

- Sample Size

The population being large the survey was carried among 100 respondents aged 20-25, most of them are the working class of Ernakulam city.

\section{Review of Literature}

Single people who lived alone in 2013 spent, on an average of $\$ 3,654$ on food. Single people who spend very little time at home spend more on entertainment like for cable connection, movies, and videogames. The term lifestylemeans interests, opinions, behaviours, and behavioural orientations of an individual, group, or culture. The term was originally used by Austrian psychologist Alfred Adler (1870-1937).

A note on consumer spending habits in India (2007) here a comparison is done on consumer spending habits in 2002 with those in 2007 which revealed that expenditure on food, clothing and personal care has remained more or less constant, but expenditure on entertainment has increased which means people spend more on their entertainment.

\section{Data Analysis}

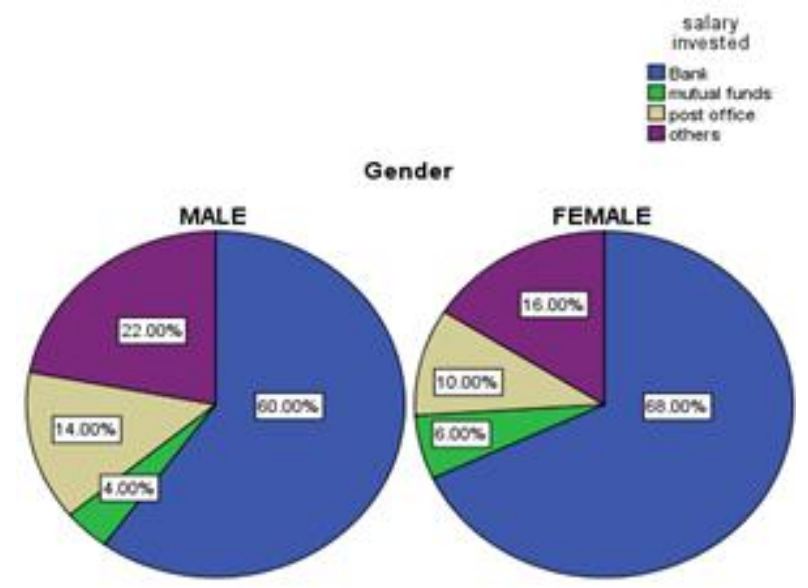

Figure 1: Salary invested by young singles 


\section{International Journal of Science and Research (IJSR) \\ ISSN (Online): 2319-7064 \\ Index Copernicus Value (2013): 6.14 | Impact Factor (2015): 6.391}

According to the data youth on average spend on bank savings, in which males spend about $60 \%$ of their salary and females spend $68 \%$. When it comes to mutual funds and post office savings males spend $4 \%$ and $14 \%$ respectively on the other hand female spend $6 \%$ and $10 \%$ respectively.

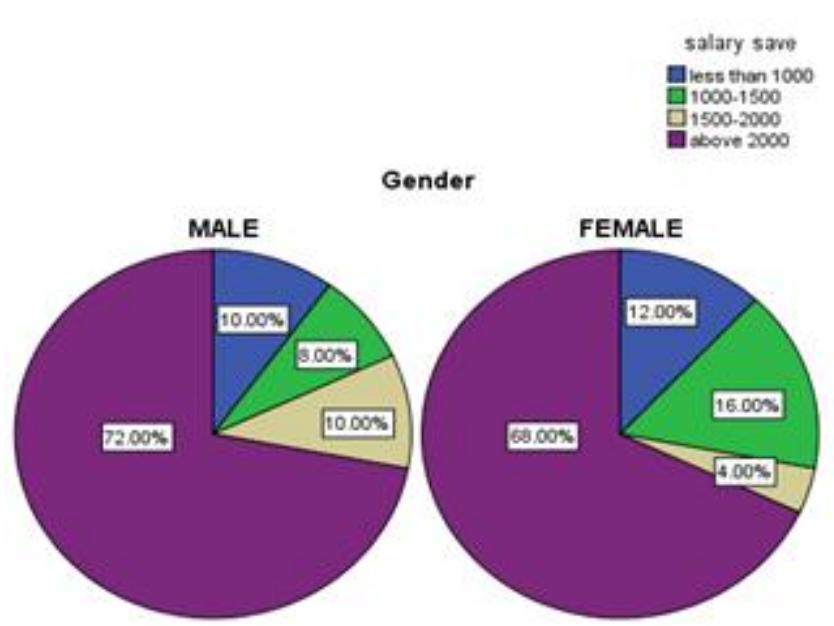

Figure 2: Amount of salary saved

According to the data, men who save less than Rs 1000 is $10 \%$ and females $12 \%$, while in case of youth saving between Rs $1000-1500$ females save $16 \%$ which is more than males who save only $8 \%$. On the other hand youth who save between Rs 1500-2000, and above Rs 2000 males save more in both the cases which is $10 \%$ and $72 \%$ respectively while females save only $4 \%$ and $68 \%$ respectively.

\section{Income Spend on Transportation}

According to the data, the males who spend less than Rs 500 on transportation is $24 \%$ and females are $30 \%$. In the case of amount ranging between Rs 500-1000 males spend 34\% and females $28 \%$, while in the case of youth spending between Rs 1000-1500 and more than Rs 1500 males and females spend equally.

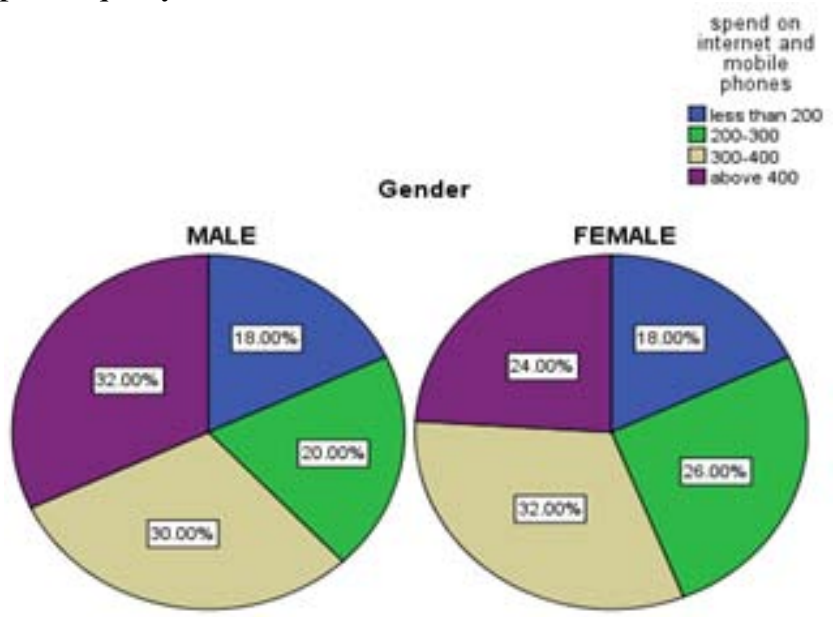

Figure 3: Income spend on mobile phones and internet In the case of money spend on mobile phones and internet males and females who spend less than 200 is $18 \%$. While money spend between Rs $200-300$ by males is $20 \%$ and females are 26\%. Amount spend between Rs 300-400 by males is $30 \%$ and females are $32 \%$ and amount spend by males above Rs 400 is $32 \%$ and females are $24 \%$.
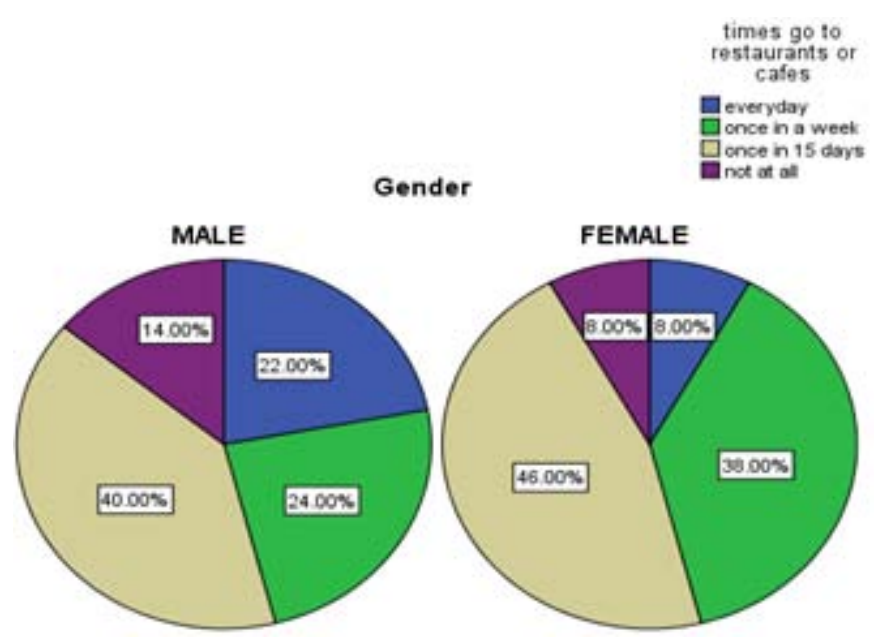

Figure 4: Money spend on food

The graph shows us that, males who go to cafes and restaurants everyday on an average is more than females which is $22 \%$ and $8 \%$ respectively. While on the other hand females go almost every week to cafes more than males which is $38 \%$ and $24 \%$ respectively. While comparing about consumption behaviour of males and females once in 15 days females consume more that is $46 \%$ and males are $40 \%$.

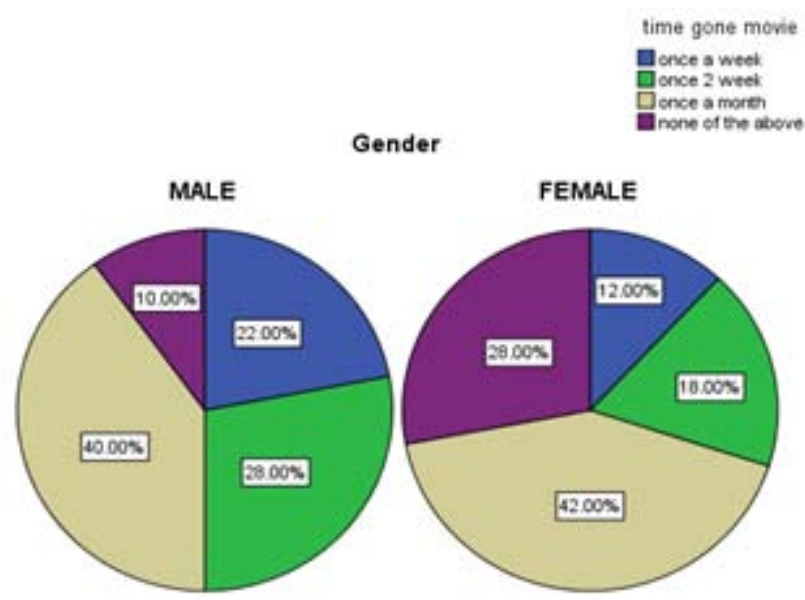

Figure 5: Time spend for watching movies

When it comes to going for movie $28 \%$ of females and $10 \%$ of males don't watch at all. And there is a section of people who watch movie once a week of which $22 \%$ is males and $12 \%$ are females. Only $18 \%$ of females go for movie once in two weeks and males 28\%. Most of the males and females who watch movies once in the month are $40 \%$ and $42 \%$ respectively.

\section{Suggestions}

- The youth should try to use their income in proper way they can invest more in mutual funds, shares and post office savings.

- The money spend on internet, phones, movies can be utilised for some other investment like buying a home or for education. 


\section{International Journal of Science and Research (IJSR) \\ ISSN (Online): 2319-7064}

Index Copernicus Value (2013): 6.14 | Impact Factor (2015): 6.391

\section{Conclusion}

The youth are investing their salary more in banks and mutual funds. The males save major part of their income on the other hand females spend more on food and movies.

\section{References}

[1] (2015)Mia Taylor , How to save Money when you are single

[2] (2009)Florin-Marius,Savings-Investments Relationship in an Open Economy

[3] Alban (2015). Top 5 things men and women choose to spend their money on.

[4] Prof.CA Yogesh P. Patel, Prof. CS Charul Y Patel(2012) A study of investment perspective of salaried people (Private Sector) 